\title{
Advancement in treatment for esophageal disease
}

In the era of minimally invasive surgery, treatment for esophageal disease has experienced many changes. Similar to most other surgical subspecialties, minimally invasive surgery has become the standard technique for many conditions of the esophagus. Although laparoscopy and thoracoscopy remain widely used and are efficient means of minimally invasive esophageal surgery, advancements in the robotic platform have led to increased usage in nearly all aspects of foregut surgery. Treatment of both benign and malignant esophageal pathology with the surgical robot yields the potential benefits of improved visualization, increased instrument range of motion, and ergonomic optimization for the operating surgeon. Furthermore, robotic surgery has allowed some surgeons to transition more effectively from predominantly open to minimally invasive approach. From an endoscopic standpoint, a number of esophageal conditions, such as diverticula of the cervical esophagus and reflux disease, can be treated by total endoscopic techniques in some cases with no external incisions. As technology, experience, and innovation progress further, esophageal surgeons will continue to have a diverse array of treatments options for common and complex esophageal disease.

\section{Acknowledgments}

Funding: None.

\section{Footnote}

Provenance and Peer Review: This article was commissioned by the editorial office, Fournal of Visualized Surgery for the series "Advancement in Treatment for Esophageal Diseases". The article did not undergo external peer review.

Conflicts of Interest: The author has completed the ICMJE uniform disclosure form (available at https://jovs.amegroups. com/article/view/10.21037/jovs-2019-28/coif). The series "Advancement in Treatment for Esophageal Diseases" was commissioned by the editorial office without any funding or sponsorship. DZL served as an unpaid Guest Editor of the series and serves as an unpaid editorial board member of Fournal of Visualized Surgery from April 2019 to March 2021. The author has no other conflicts of interest to declare.

Ethical Statement: The author is accountable for all aspects of the work in ensuring that questions related to the accuracy or integrity of any part of the work are appropriately investigated and resolved.

Open Access Statement: This is an Open Access article distributed in accordance with the Creative Commons AttributionNonCommercial-NoDerivs 4.0 International License (CC BY-NC-ND 4.0), which permits the non-commercial replication and distribution of the article with the strict proviso that no changes or edits are made and the original work is properly cited (including links to both the formal publication through the relevant DOI and the license). See: https://creativecommons.org/ licenses/by-nc-nd/4.0/. 


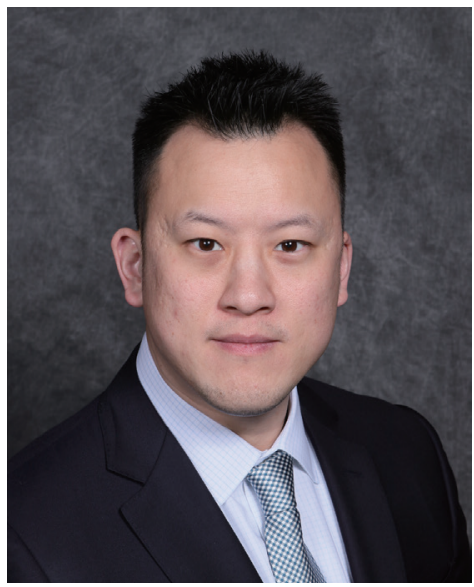

Douglas Z. Liou

Douglas Z. Liou

Division of Thoracic Surgery, Department of Cardiothoracic Surgery, Stanford University School of Medicine, Stanford, CA, USA. (Email: dliou@stanford.edu) Received: 03 July 2020; Accepted: 27 July 2020; Published: 20 January 2021. doi: 10.21037 /jovs-2019-28

View this article at: http://dx.doi.org/10.21037/jovs-2019-28

doi: 10.21037/jovs-2019-28

Cite this article as: Liou DZ. Advancement in treatment for esophageal disease. J Vis Surg 2021;7:1. 